\title{
The Role of yoghurt on dental erosion
}

\author{
Alisa Zayadi, Rini Bikarindrasari, Danica Anastasia \\ Department of Conservative Dentistry \\ Faculty of Medicine, University of Sriwijaya, Palembang
}

\section{ABSTRACT}

Dental erosion is defined as irreversible loss of dental hard tissue, caused by acid condition in the oral cavity without bacterial involvement. One of the signs of dental erosion is calcium dissolution of the enamel. Yoghurt is a fermented beverage that has low $\mathrm{pH}$ level due to lactic acid. The aim of this study was to measure the solubility of calcium enamel after soaking in yoghurt for 12 and 18 hours. Twenty-four premolars were divided into 4 groups. Group A and B were soaked in milk for 12 and 18 hours; group $C$ and D were soaked in yoghurt for 12 and 18 hours. Atomic Absorption Spectrophotometer (AAS) was used to measure the solubility of calcium from each sample. Data were analyzed using one-way ANOVA and LSD $(p<0.05)$. This study indicated that soaking premolars in yoghurt for 18 hours has greater enamel calcium dissolution than in yoghurt for 12 hours. It can be concluded that prolonged soaking premolars in yoghurt will increase the calcium enamel dissolution.

Key words: dental erosion, yoghurt, pH level, Calcium dissolution.

\section{ABSTRAK}

Erosi gigi didefinisikan sebagai proses hilangnya jaringan keras gigi yang bersifat irreversibel, sebagai akibat dari kondisi asam di rongga mulut tanpa ada keterlibatan bakteri. Larutnya kalsium yang berasal dari. Kristal kalsium hidroksiapatit email merupakan salah satu tanda erosi gigi. Yoghurt adalah minuman hasil fermentasi yang memiliki pH rendah karena mengandung asam laktat. Tujuan penelitian ini adalah untuk mengukur kelarutan kalsium email gigi premolar setelah perendaman dalam yoghurt selama 12 jam dan 18 jam. Dua puluh empat gigi premolar dibagi menjadi 4 kelompok. Kelompok pertama direndam dalam susu selama 12 jam, kelompok kedua direndam dalam susu selama 18 jam, kelompok ketiga direndam dalam yoghurt selama 12 jam, dan kelompok keempat direndam dalam yoghurt selama 18 jam. Spektofotometer Serapan Atom (SSA) digunakan untuk mengukur kelarutan kalsium dari masing-masing sampel. Data dianalisis menggunakan one way ANOVA dan LSD ( $p<0.05)$. Hasil yang didapatkan menunjukkan bahwa gigi yang direndam dalam yoghurt selama 18 jam menunjukkan peningkatan kelarutan kalsium email yang lebih besar dibandingkan gigi yang direndam dalam yoghurt selama 12 jam. Semakin lama gigi premolar direndam dalam yoghurt akan semakin besar kelarutan kalsium email yang ditimbulkannya.

Kata kunci: erosi gigi, yoghurt, keasaman, kalsium. 


\section{INTRODUCTION}

Dental erosion is a chemical process that causDental erosion is a chemical process that causes loss of dental hard tissues, which is a permanent condition. ${ }^{1,2}$ It occurs when teeth come into contact with intrinsic and/or extrinsic acid solution without any bacterial activity. ${ }^{2,3}$ Nowadays, many people consume yoghurt twice a day regularly because it is considered as a high nutritious healthy drink and is believed able to cure some metabolic diseases. ${ }^{4}$ However, yoghurt contains lactic acid with low pH levels, which might cause problems on enamel when consumed regularly for a long period. The $\mathrm{pH}$ level is approximately $3.5-4.1$ that can lower the $\mathrm{pH}$ of the oral cavity up to 5.5 shortly after consumption. This situation can cause dental erosion. ${ }^{5,6,7}$

Cornelius Tokunbo Bamise (University of Obafemi Awolowo, Nigeria) stated that if yoghurt is drank little by little in a few minutes can cause acidity in the oral cavity lasts longer, and increase the potential of dental erosion. ${ }^{6}$ In 2007, The Academy of General Dentistry reveals that yoghurt is one of drinks with low pH that could potentially cause dental erosion. ${ }^{8}$ Lactic acid in yoghurt is responsible for causing damage in child's teeth when consumed excessively. ${ }^{9}$ Other studies carried out in Istanbul towards 153 children aged $11-14$ years old, informed $36 \%$ of dental erosion lesions in children who consume fruit yoghurt routinely. ${ }^{10}$ Many of the existing studies did not clearly mentioned the frequency of drinking yoghurt that might be dangerous and the required exposure time to the occurrence of dental erosion.

Based on the description above, the author was interested to find out the contact time required by the yoghurt to cause dental erosion.

\section{MATERIAL AND METHODS}

This research was an experimental laboratory study with the population 24 premolars that had been removed for orthodontic purposes and were caries-free. Samples of this study were taken randomly, and divided into four groups. Each groups contained 6 samples; group A and B were soaked in milk for 12 and 18 hours; group $C$ and D were soaked in yoghurt for 12 and 18 hours. The study was conducted at the Chemical
Analysis Laboratory of the Faculty of Mathematics, University of Sriwijaya in September 2012.

Soaking time was determined by specific calculations. From the observation, the duration of yoghurt consumption at a time was 1 minute. So, to observe the effect of dental erosion from consumers who regularly drink the recommended consumption of yoghurt, which was twice a day, were obtained from the following calculation:

\section{1 minute $\times 2 \times 365$ days $=730$ minutes $/$ year $= \pm 12$ hours $/$ day}

To observe the effect of yoghurt consumption from consumers who regularly drink more than the recommended consumption, which were 3 times a day, were obtained from the following calculation:

\section{1 minute $\times 3 \times 365$ days $=1.095$ minutes $/$ year $= \pm 18$ hours $/$ day}

Research was carried out using tools and materials; $20 \mathrm{ml}$ sealed plastic tube for soaking the samples, measuring cup, milk, and yoghurt brand $\mathrm{X}$; Atomic Absorption Spectrophotometer (AAS), $10 \mathrm{ml}$ measuring cup, $1 \mathrm{ml}$ volumetric pipette, 5 $\mathrm{ml}$ measurement pipette, mineral water, calcium standard solution $1000 \mathrm{mg} / \mathrm{L}$, calcium standard solution (ppm), acetylene gas $\left(\mathrm{C}_{2} \mathrm{H}_{2}\right)$, and diluting solution (aquadest distilled).

Each sample is given a sequence number corresponding groups ( $A 1, A 2$, etc; $B 1, B 2$, etc; $C 1$, C2, etc; and D1, D2, etc). Furthermore tooth roots were coated with nail polish to prevent calcium apart than those from enamel; $\mathrm{pH}$ level of yoghurt was measured to ensure it is below the critical point $(\mathrm{pH}<5.5)$. Levels of calcium in milk and yoghurt were measured before soaking the teeth. Measurement of calcium dissolution of yoghurt was with Atomic Absorption. Solution needed for each measurement was about $10 \mathrm{ml}$ per sample. Data obtained was tabulated for each group. Then, Shapiro-Wilk test and Levene's test were used to determine the distribution and homogeneity of the data. Furthermore, the data was analyzed using One Way Anova, followed by Least Significant Difference (LSD) test to determine which group was significantly different using, 95\% level of confidence $(\alpha=0.05)$. 


\section{RESULTS}

The result obtained before and after immersion of the samples in yoghurt and milk as control, respectively after 12 and 18 hours, can be seen in Table 1.

Table 1. Calcium levels (ppm) before and after immersion for 12 hours and 18 hours in milk and yoghurt.

\begin{tabular}{ccccccccc}
\hline Sample & \multicolumn{2}{c}{ Group A } & \multicolumn{2}{c}{ Group B } & \multicolumn{2}{c}{ Group C } & \multicolumn{2}{c}{ Group D } \\
\cline { 2 - 9 } Number & $\mathbf{0}$ & $\mathbf{1 2 ~ h r}$ & $\mathbf{0}$ & $\mathbf{1 8} \mathrm{hr}$ & $\mathbf{0}$ & $\mathbf{1 2} \mathbf{h r}$ & $\mathbf{0}$ & $\mathbf{1 8} \mathrm{hr}$ \\
\hline 1 & 325.47 & 325.79 & 315.20 & 315.58 & 356.94 & 360.95 & 353.38 & 357.92 \\
2 & 310.35 & 310.82 & 326.82 & 327.15 & 362.41 & 366.69 & 359.97 & 365.29 \\
3 & 327.34 & 327.68 & 331.65 & 331.90 & 355.73 & 359.49 & 351.30 & 356.48 \\
4 & 335.19 & 335.40 & 321.91 & 322.32 & 360.44 & 364.78 & 363.45 & 368.01 \\
5 & 321.10 & 321.16 & 328.59 & 328.76 & 362.02 & 366.13 & 365.57 & 369.94 \\
6 & 324.73 & 325.02 & 324.98 & 325.45 & 357.29 & 361.16 & 355.70 & 360.63 \\
Mean & 324.03 & 324.31 & 324.85 & 325.19 & 359.14 & 363.20 & 358.23 & 363.05 \\
\hline
\end{tabular}

The difference between levels of calcium ions before and after immersion of the samples showed the amount of calcium dissolved in enamel, which can be seen in table 2 .

Table 3. The LSD test result.

\begin{tabular}{ccccc}
\hline \multirow{2}{*}{ Sample Number } & \multicolumn{4}{c}{ Group } \\
\cline { 2 - 5 } & A & B & C & D \\
\hline 1 & 0.32 & 0.38 & 4.01 & 4.54 \\
2 & 0.47 & 0.33 & 4.28 & 5.32 \\
3 & 0.34 & 0.25 & 3.76 & 5.18 \\
4 & 0.21 & 0.41 & 4.34 & 4.56 \\
5 & 0.06 & 0.17 & 4.11 & 4.37 \\
6 & 0.29 & 0.47 & 3.87 & 4.93 \\
Mean & 0.28 & 0.34 & 4.06 & 4.82 \\
\hline Standard Deviation & 0.137 & 0.109 & 0.227 & 0.384 \\
\hline
\end{tabular}

Shapiro-Wilk normality test was then conducted in order to determine the normal data distribution, at the significance level $>0.05$ which meant that the data was normally distributed. Next, homogeneity test was performed, resulting the value of 0.351 . This indicates that there was a significant difference between the control group (milk) and the yoghurt group. In order to determine the difference of amount of dissolved calcium in enamel between the control group (milk) and yoghurt group, LSD test was performed.
Table 2. Amount of dissolved calcium in enamel (ppm).

\begin{tabular}{cccc}
\hline \multicolumn{2}{c}{ Group Sample } & Mean Difference & Significance \\
\hline A & B & 0.059 & 0.340 \\
& C & $1.502^{*}$ & 0.000 \\
& D & $1.680^{*}$ & 0.000 \\
B & C & $1.443^{*}$ & 0.000 \\
& D & $1.621^{*}$ & 0.000 \\
C & D & $0.179^{*}$ & 0.008 \\
\hline
\end{tabular}

Based on the above table, it indicated a significant difference $(p<0.05)$ between groups $A$ and $C$, groups $A$ and $D$, groups $B$ and $C$, groups $B$ and $D$, as well as between groups $C$ and $D$. While between groups $A$ and $B$ showed no significant differences, which can be seen from the significant value of $0.340(p>0.05)$.

\section{DISCUSSION}

The data contained in table 2 shows the results of varying solubility of calcium ions from each sample group. The average value of the solubility of calcium in enamel after soaking in milk for 12 hours and 18 hours showed the 0.28 $\mathrm{ppm}$ and $0.34 \mathrm{ppm}$. Based on the results of LSD test, both treatment groups showed no significant difference, meaning long immersion premolar tooth in milk had no effect on calcium solubility of 
tooth enamel. This result is in accordance with Sri Soebekti statement saying that the acidic water can cause erosion gigi. ${ }^{11}$ While in this study, $\mathrm{pH}$ level of milk is neutral ( $\mathrm{pH} \mathrm{7)}$ so it does not risk causing dental erosion.

The average value of the solubility of calcium enamel in the yoghurt after soaking for 12 hours and 18 hours were $4.06 \mathrm{ppm}$ and $4.08 \mathrm{ppm}$. It is greater than the solubility of calcium enamel soaked in milk. From results of LSD test, group $C$ and $D$ have significant differences of enamel calcium solubility when compared with the group $A$ and $B$. This can occur due to differences in $\mathrm{pH}$ of the two types of beverages. The difference in the value of calcium solubility of tooth enamel in each treatment group is shown in chart 1.

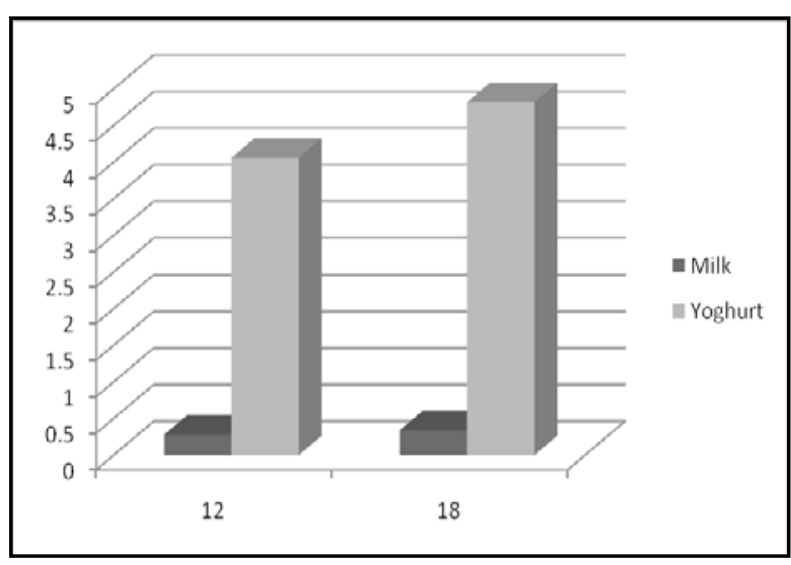

Diagram 1. The average value of the solubility of calcium ions in milk and yoghurt.

This result is consistent with the statement of the Academy of General Dentistry in 2012 which said that yoghurt is one of the drinks with low $\mathrm{pH}$ that could potentially caused dental erosion. ${ }^{8}$ Yoghurt contains lactic acid, has a pH level of 4, and the erosive nature, so as to trigger the process of tooth demineralization. Shortly after drinking yoghurt, $\mathrm{pH}$ level of the oral cavity decrease below the critical point $(<5.5)$, which is a saturation point of saliva resulting in demineralization of enamel dissolution into the oral environment. About 30 minutes after contact with acidic beverages, oral cavity $\mathrm{pH}$ level is gradually increased to normal, called remineralization. ${ }^{7}$ But if yoghurt is consumed slowly little by little in a few minutes longer than the consumption should be, then remineralization process will be delayed. ${ }^{6}$
Teeth soaked in yoghurt for 18 hours had an average value of dissolved calcium levels greater than soaked in yoghurt for 12 hours. This is consistent with previous studies conducted by Susi Susanti to determine the effect of the acidity of soft drinks on the release of enamel calcium. ${ }^{12}$ The study was conducted by immersing premolars into tea and cola beverages for 3.5 days and 7 days. The results showed that after immersing in tea with $\mathrm{pH}$ level 6.7 in 3.5 days calcium enamel was dissolved at 5.80 ppm and after 7 days at 6.67 ppm. The teeth soaked in cola with a pH level of 2.5, after 3.5 days obtained calcium dissolution of enamel at 97.53 ppm and after 7 days at 165.39 ppm. Analyzing the measured results of these two studies, it could be concluded that the more teeth contact with acidic drinks, the greater calcium dissolution of enamel occurs.

\section{CONCLUSION}

Based on the above, it can be concluded that there are elevated levels of calcium ions released from enamel after immersion in milk or yoghurt. Immersion in yoghurt increased enamel calcium solubility greater than in milk. The longer the tooth was immersed in yoghurt, the higher solubility of enamel calcium occurs. Thus, it can be concluded that the more consumption of yoghurt, the greater risk of will be dental erosion.

\section{REFERENCES}

1. Dorland WAN. Kamus Kedokteran Dorland. Editor: Hartanto H, dkk. 29ed th. Jakarta: EGC; 2002. Enamel; p.759, 725.

2. Imfeld T. Dental erosion. Definition, classification and links. Eur J Oral Sci; 1996: 104:151-5.

3. Mahoney EK. Kilpatrick NM. Dental Erosion: Part 1. Aetiology and Prevalence of Dental Erosion. J New Zealand:June 2003;99(2):3341.

4. Widodo W. Bioteknologi Fermentasi Susu. Pusat Pengembangan Bioteknologi Universitas Muhammadiyah Malang: 2002. p.1-27.

5. Kidd E. Dental Caries: The Disease and Its Clinical Management. $2^{\text {nd }}$ ed. Blackwell Munksgaard; 2008. p.33-46. 
6. Bamise CT, Bamise OF. Quantifying the Acid Content of Commercial Yoghurt Drinks in Nigeria. Nigeria: Internet J Dent Scien. 2008:6 (1).

7. Dowes $\mathrm{C}$. What is critical $\mathrm{pH}$ and why does a tooth dissolve in acid. J Can Dent Assoc 2003; 69: 722-4.

8. The Academy of General Dentistry. AGD Launce Campaign to Fokcus on Tooth Erosion. Available from:www.agd.org, Cited [2012 Mar 27].

9. Çaglar E, Kargul B, Tanboga I, Lussi A. Dental Erosion Among Children in an Istanbul Public School. J Dentis Child. 2005; 72(1): 5-9.

10. Hanning C, Hamkens A, Becker $\mathrm{K}$, Attin T. Erosive Effect of Different Acid on Bovine
Enamel: Calsium Release of Calcium and Phosphate in Vitro. Arch Oral Biology. 2005 Jun; 50(6):541-52.

11. Soebekti $\mathrm{S}$. Hubungan penggunaan air minum yang mengandung timah dan bersifat asam dengan erosi gigi. Post Graduate Program University of Airlangga. Surabaya: 1993. p.2443.

12. Susanti S. Pengaruh Keasaman Minuman Ringan Terhadap Pelepasan Ion Kalsium Pada Email Gigi. Universitas of Sriwijaya. Palembang: 2008.

13. Ilyas M. Perbedaan Kadar Kalsium dalam Saliva Sebelum dan Sesudah Mengkonsumsi Minuman Ringan yang Mengandung Asam Bikarbonat. Dentofasial: Oktober 2007;6(2):111-5. 